Gut, 1968, 9, 48-51

\title{
Some experience with deglycyrrhizinated liquorice in the treatment of gastric and duodenal ulcers with special reference to its spasmolytic effect
}

\author{
S. N. TEWARI AND F. C. TREMBALOWICZ \\ From the Wakefield Group of Hospitals
}

Liquorice has been used in medicine for many years, originally as a sweetening agent, but its efficacy was not fully realized until Revers $(1946,1958)$ found that peptic ulcers healed rapidly with its extract. However, oedema, heartburn, congestive cardiac failure, and headaches were commonly encountered as side effects of the crude extract. Molhuysen, Gerbrandy, de Vries, de Jong, Renstia, Turner, and Borst (1950) confirmed these findings and attributed them to retention of water and sodium chloride. Moreover, they also observed an increase in excretion of potassium which was later demonstrated by Revers (1951). Revers (1952) found that if glycyrrhizinic acid was removed from liquorice the oedema did not occur in one of his patients but it reappeared when the whole liquorice was administered. Nelemans-Stamperius (1949) showed by experiments in vitro that liquorice inhibited intestinal spasm caused by acetylcholine or barium chloride, a result which was subsequently confirmed by Aarsen and Van Noordwijk (1963).

\section{METHOD}

Deglycyrrhizinated liquorice, as caved-S tablets, containing deglycyrrhizinated powdered block liquorice $380 \mathrm{mg}$., bismuth subnitrate $100 \mathrm{mg}$., aluminium hydroxide gel $100 \mathrm{mg}$., magnesii carbonas levis $200 \mathrm{mg}$., sodium bicarbonate $100 \mathrm{mg}$., powdered frangula bark $30 \mathrm{mg}$., in each tablet were given to patients with gastric or duodenal ulcers and the results were compared with those of inert tablets of the same composition except that each tablet contained lactose flavoured with aniseed to simulate the taste of liquorice. The degree of correspondence was virtually identical.

Both active and inert preparations were given a double blind trial of four weeks in all duodenal and gastric ulcer patients. The therapy was crossed over in all six gastric ulcer patients and only in $\mathbf{1 5}$ of the $\mathbf{5 0}$ duodenal ulcer patients, who were subjected to sequential analysis (Table III). The assessment was carried out without knowledge of which individuals were in the test and which in the control groups. Following the method of Doll (1964), only patients whose gastric ulcers had a profile size greater than $10 \mathrm{sq} . \mathrm{mm}$. were included. All duodenal ulcer patients had typical symptoms at the start of the trial and had an ulcer crater or deformity of the duodenal cap demonstrable on a barium meal. The hospital pharmacists arranged the random distribution of equal numbers in each group receiving either drug or inert tablets. Patients were advised to chew two tablets three times daily after meals. Only a known antacid, Alcin (360 mg. anhydrous co-prepared sodium magnesium aluminium silicate and basic magnesium aluminate per tablet), was allowed to be used through the period of the trial. Each patient was advised to suck the antacid given; if he experienced pain or suffered excessive heartburn while receiving the drug or placebo he was asked to note down the numbers of Alcin tablets consumed each day and present the chart at his next attendance. No dietary, drinking, or smoking restriction was imposed. All patients were treated while fully ambulant and carrying out their normal work. The patients were reviewed weekly in the first instance and then every two weeks by different members of the Medical Unit to prevent any personal individual bias. At each attendance, the patients were weighed, blood pressures measured, and their progress was classified. The number of Alcin tablets consumed was recorded. Progress was classified 'good' if the patient had no pain, nausea, vomiting, and flatulence in the past two weeks; 'improved' if the patient had one or two mild episodes of pain with slight nausea, vomiting, and flatulence in the previous two weeks; 'not improved' if the patient had pain, nausea, vomiting, and flatulence more or less every day. They were particularly questioned about nocturnal pain and pain before or after food. A full blood count, including blood urea and examination of the urine, was done in all cases; readings for serum electrolytes, thymol turbidity, and transaminases in most cases and electrocardiograms before and after the period of trial were available in all cases.

\section{RESULTS}

Fifty-six patients were admitted to the double blind trial of whom six had gastric ulcers and 50 duodenal ulcers. One duodenal ulcer patient on active therapy developed diarrhoea and stopped the treatment, and another one also on active therapy failed to 
keep his appointment. These two were excluded from the trial. Fifty-four patients completed the trial. Of these 54 patients, 30 were males and 24 females, with an age range from 12 to 90 years. The duration of symptoms varied between four months and 20 years. The average in group I was 5.8 years and in group II 6.4 years. The age and sex distribution are shown in Table Ia. Table $I$ also shows that the total $\chi^{2}$ is 31.59 for 2 degrees of freedom. In gastric ulcer patients the size of the ulcer crater was measured in profile in square millimetres and the results before and after treatment are shown in Table II. In the first four weeks three patients treated with inert tablets did not show any change in size of the ulcer crater and when the therapy was crossed over, one showed diminution in size of the crater from $60 \mathrm{sq} . \mathrm{mm}$. to $20 \mathrm{sq}$. $\mathrm{mm}$. The remaining three patients treated with the active preparation showed complete healing in the first four weeks. In the course of the follow-up period when the therapy was crossed over in 15 patients with duodenal ulcers, they were studied for sequential analysis. Four patients were omitted here as they did not show their preference for either an active or an inactive tablet and only the preferences are recorded. In this analysis, the results were classified as 'improved' or 'not improved' and summarized in Table III, which shows a beneficial effect in the drugtreated group. The preferences were plotted sequentially according to the method of Armitage (1960). The restricted design was used: $2 X=0.05$, $1-b=0.95,0=0.85$. These results are shown in

TABLE I

NUMBERS OF PATIENTS TREATED WITH CAVED-S (GROUP I) VERSUS INERT (GROUP II) TABLETS

Result Observed $(O)$ No. Total Expected $O-E^{2} / E$ (E) No.

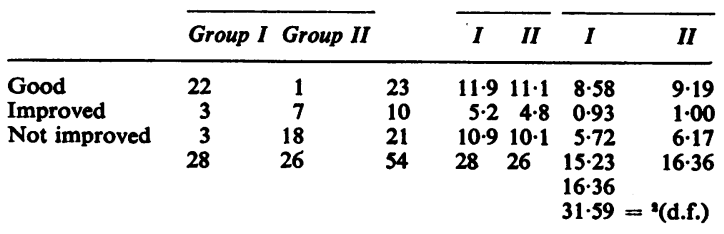

TABLE IA

DIVISION OF THE PATIENTS ADMITTED TO THE DOUBLE BLIND TRIAL BY SEX AND AGE

\begin{tabular}{|c|c|c|c|c|}
\hline \multirow{2}{*}{$\begin{array}{l}\text { Age Group } \\
\text { (yr) }\end{array}$} & \multicolumn{2}{|c|}{ Group I: Active Tablets } & \multicolumn{2}{|c|}{ Group II: Inert Tablets } \\
\hline & Male & Female & Male & Female \\
\hline $\begin{array}{l}11-20 \\
21-40 \\
41-60 \\
61-80 \\
81-90 \\
\text { Total }\end{array}$ & $\begin{array}{r}1 \\
5 \\
6 \\
2 \\
1 \\
15\end{array}$ & $\begin{array}{r}-3 \\
7 \\
3 \\
13\end{array}$ & $\begin{array}{r}1 \\
2 \\
10 \\
2 \\
15\end{array}$ & $\begin{array}{r}-3 \\
7 \\
1 \\
11\end{array}$ \\
\hline
\end{tabular}

TABLE II

RESULTS OF TREATMENT WITH CAVED-S TABLETS ASSESSED BY CHANGE IN SIZE OF GASTRIC ULCER

\begin{tabular}{|c|c|c|c|}
\hline \multirow{3}{*}{$\begin{array}{l}\text { Patient } \\
\text { No. }\end{array}$} & \multicolumn{3}{|c|}{ Size of Ulcer ( $\left.\mathrm{mm} .{ }^{2}\right)$} \\
\hline & \multirow{2}{*}{$\begin{array}{l}\text { Before } \\
\text { Treatment }\end{array}$} & \multicolumn{2}{|l|}{ After Treatment } \\
\hline & & $\begin{array}{l}\text { First Four Weeks } \\
\text { (inert) }\end{array}$ & $\begin{array}{l}\text { Second Four Weeks } \\
\text { (drug) }\end{array}$ \\
\hline $\begin{array}{l}1 \\
2 \\
3\end{array}$ & $\begin{array}{l}97 \\
60 \\
95\end{array}$ & $\begin{array}{c}97 \\
60 \\
95 \\
\text { (drug) }\end{array}$ & $\begin{array}{c}0 \\
20 \\
0 \\
\text { (inert) }\end{array}$ \\
\hline $\begin{array}{l}4 \\
5 \\
6\end{array}$ & $\begin{array}{r}64 \\
650 \\
463\end{array}$ & $\begin{array}{l}0 \\
0 \\
0\end{array}$ & $\begin{array}{l}\mathbf{0} \\
\mathbf{0} \\
\mathbf{0}\end{array}$ \\
\hline
\end{tabular}

TABLE III

RESULTS IN DUODENAL ULCER PATIENTS INCLUDED IN THE SEQUENTIAL TRIAL

\begin{tabular}{|c|c|c|c|c|c|}
\hline \multirow{2}{*}{$\begin{array}{l}\text { Patient } \\
\text { No. }\end{array}$} & \multirow{2}{*}{$\begin{array}{c}\text { Age } \\
(y r)\end{array}$} & \multicolumn{2}{|c|}{ Caved-S Tablets } & \multicolumn{2}{|l|}{ Inert Tablets } \\
\hline & & $\begin{array}{l}\text { Improved } \\
(+) \text { or Not } \\
\text { Improved } \\
(-)\end{array}$ & $\begin{array}{l}\text { No. of Alcin } \\
\text { Tablets/ } \\
\text { Week }\end{array}$ & $\begin{array}{l}\text { Improved } \\
(+) \text { or Not } \\
\text { Improved } \\
(-)\end{array}$ & $\begin{array}{l}\text { No. of Alcin } \\
\text { Tablets/ } \\
\text { Week }\end{array}$ \\
\hline 1 & 41 & + & 5 & - & 10 \\
\hline 2 & 62 & + & 0 & - & 2 \\
\hline 3 & 52 & - & 10 & + & 1 \\
\hline 4 & 32 & + & 6 & - & 10 \\
\hline 5 & 30 & - & 0 & - & 25 \\
\hline 6 & 42 & + & - & - & - \\
\hline 7 & 62 & + & 0 & - & 3 \\
\hline 8 & 50 & + & 4 & - & 6 \\
\hline 9 & 66 & + & 0 & - & 6 \\
\hline 10 & 50 & - & 2 & - & 2 \\
\hline 11 & 41 & + & 4 & - & 7 \\
\hline 12 & 36 & + & 0 & - & 0 \\
\hline 13 & 57 & + & 2 & + & 12 \\
\hline 14 & 67 & + & 0 & + & 0 \\
\hline 15 & 33 & + & 7 & - & 8 \\
\hline & & & $\begin{array}{c}40 \\
\mathrm{~m}=2.6\end{array}$ & & $\mathrm{~m} \stackrel{92}{=} 6.1$ \\
\hline
\end{tabular}

Figure 1. This figure shows that the upper boundary was reached at $\mathbf{n}=10$. Table III shows the difference in the number of Alcin tablets consumed per week between the two groups. The mean number of Alcin tablets consumed by the patients under active therapy was 2.6 per week while patients on inert tablets consumed an average of 6.1 Alcin tablets a week. Two patients on active therapy developed slight diarrhoea, one of whom improved while treatment was continued. Other untoward symptoms noted varied from slight heaviness in the head and headaches to dizziness in two others, but no rise in blood pressure was noted. Two patients had a weight increase of $5 \mathrm{lb}$. and the third of $8 \mathrm{lb}$., but there was neither demonstrable pitting oedema nor changes in the blood pressure. No instance of hypokalaemia, clinical or biochemical, was noted.

In the second part of the trial, an attempt was made to study the effect of the drug on spasticity of 


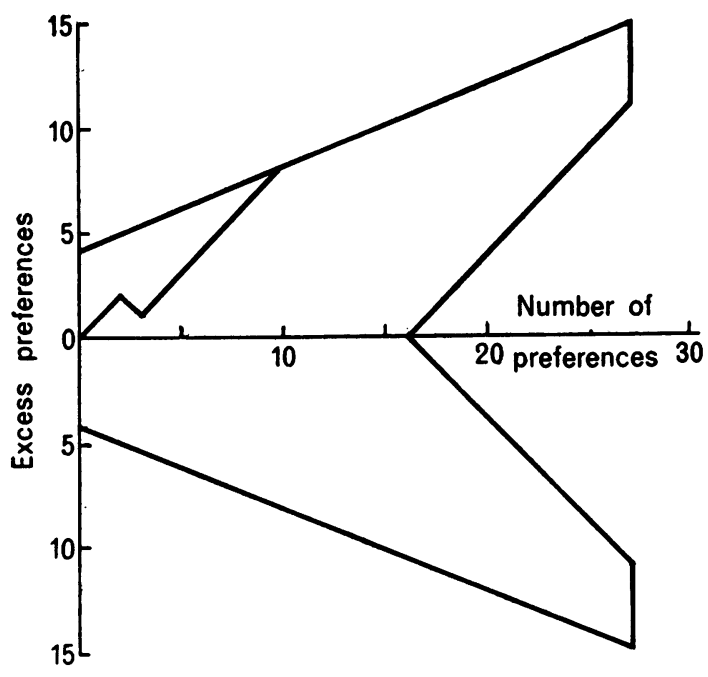

FIG. 1. Results plotted sequentially according to the method of Armitage (1960) using the restricted design.

the duodenal cap during screening. The filling and emptying times were assessed during screening only; measurement of the diameter of the duodenal cap was not possible without the aid of cine-radiography, the facility for which was not available. A radiological study was performed on 50 patients with duodenal ulcers in an attempt to elucidate the mode of action of deglycyrrhizinated liquorice. The pure drug was given to 20 patients with duodenal ulcer after spasticity of the duodenal cap had been demonstrated. After 20 minutes, rescreening showed relaxation of spasticity and better filling of the cap. A further 20 patients who did not receive any drug showed no relaxation of spasticity on rescreening at $\mathbf{2 0}$ minutes, nor did $\mathbf{1 0}$ duodenal ulcer patients who received a proprietary antacid tablet, Roter (bismuth subnitrate Roter 350 mg.; magnesium carbonate $400 \mathrm{mg}$.; sodium bicarbonate $200 \mathrm{mg}$.; cortex rhamni frangulae $25 \mathrm{mg}$. per tablet). For comparison, 40 cases without duodenal ulceration but with definite pylorospasm were studied, half receiving the pure drug and half not, but no effective relaxation of spasm was demonstrated in either group on rescreening.

\section{DISCUSSION}

In the double blind trial good results for deglycyrrhizinated liquorice have been demonstrated in gastric as well as in duodenal ulcer patients. In the duodenal ulcer patients the deformity persisted in all; the ulcer crater disappeared in five in two weeks, and the cap showed better filling in all drug-treated groups, thus suggesting the spasmolytic effect of deglycyrrhizinated liquorice. The spasmolytic effect was further demonstrated in a radiologically controlled study which showed better filling of the chronically deformed cap in duodenal ulcer patients after administration of the drug. Although the number of gastric ulcer patients treated is small the effect on healing of the ulcer compared favourably with the results obtained by Revers (1948) and Molhuysen et al. (1950). The mode of action of liquorice remains uncertain and further work is needed before any firm conclusion can be drawn. The demonstration of a crater in a chronically deformed cap is difficult; the assessment of healing of the ulcer more so.

The great advantage of this treatment is that patients can be treated ambulant and with minimum side effects. This is contrary to the experience with crude liquorice containing glycyrrhizinic acid (Revers, 1948, 1951) and Molhuysen et al. (1950). We did not encounter any evidence of pitting oedema, hypokalaemia, or rise in blood pressure as noted by Doll, Hill, Hutton, and Underwood (1962), Doll (1964), Turpie and Thomson (1965), who reported these side effects, which varied between 17 and $21 \%$ and $35 \%$ in their series using preparations of a glycyrrhizinic acid derivative (carbenoxolene).

\section{SUMMARY}

In a double blind clinical trial in which 54 patients were included, the effect of deglycyrrhizinated liquorice was investigated. Duodenal ulcer cases showed marked symptomatic improvement, with radiological healing demonstrable in a few cases. Further confirmation of the activity of the drug was obtained from the treatment of six cases of gastric ulcer all of which showed extensive healing. Radiology demonstrated that the effect of the drug was spasmolytic in all duodenal ulcer patients, and that the side-effects were minimal. The great advantage of the treatment is that patients can be treated as ambulant and with a minimum loss of work.

We are grateful to Dr. R. Fletcher and Dr. W. Meikle, consultant physicians, for allowing us to treat patients under their care; to Dr. Aarsen for his statistical comments; to the group pharmacists for their cooperation in the trial; to the Tillotts Laboratories and to Cedona, Haarlem, Holland, for supplying the drug and inert tablets.

\section{REFERENCES}

Aarsen, P. N., and van Noordwijk, J. (1963). Comparison of the spasmolytic activity of liquorice in treated and untreated form. (In German.) Ther. Umsch., 20, 302-305.

Armitage, P. (1960). Sequential Medical Trials. Blackwell, Oxford. 
Croxton, F. E. (1953). Elementary Statistics with Applications in Medicine. Prentice-Hall, New York.

Doll, R. (1964). Medical treatment of gastric ulcer. Scot. med. J., 9, 183-196.

- Hill, I. D., Hutton C., and Underwood, D. J., II (1962). Clinical trial of a triterpenoid liquorice compound in gastric and duodenal ulcer. Lancet, 2, 793-796.

Molhuysen, J. A., Gerbrandy, J., de Vries L. A., de Jong, J. C., Lenstra, J. B., Turner, K. P., and Borst, J. G. G. (1950). A Liquorice extract with a deoxycortone-like action. Lancet, 2, 381-386.

Nelemans-Stamperius, J. A. E. (1949). Liquorice and stomach ulcers. Thesis, Utrecht.
Revers, F. E. (1946). Heeft suecus liquiritiae een genezende werking op de maagzweer? Ned. T. Geneesk, 90, 135-137.

- (1948). De behandeling van ulcus ventriculi en ulcus duodeni met succus liquiritiae. Ibid., 92, 2968-2973.

- (1951). Enige eigensthappen van succus liquiritiae. Ibid., 95 , 120-124.

- (1952). Behandeling van maagzweren met succus liquiritiae, waarnit de oedeemverwekkende factor. (het glycyrrhizinezuur) is verwijderd. Ibid., 96, 2338-2341.

Turpie, A. G. G., and Thomson, T. J. (1965). Carbenoxolone sodium in the treatment of gastric ulcer with special reference to sideeffects. Gut, 6, 591-594. 